\title{
Student opinion in focus
}

\section{ÁGNES NÓTIN ${ }^{1 *}$ (1), and ANNA WARE ${ }^{2}$ (1)}

\footnotetext{
${ }^{1}$ University of Debrecen, Institute of Psychology, Egyetem tér 1, 4032 Debrecen, Hungary

${ }^{2}$ University of Debrecen, Teacher training, Egyetem tér 1, 4032 Debrecen, Hungary
}

\section{THEMATIC ARTICLE}

Published online: June 19, 2020

(C) The Author(s) 2020

\begin{abstract}
At the end of the first semester of the 2017/18 academic year, we conducted research in the form of focus groups on the attitudes of disadvantaged primary school students toward language learning and school. The students were asked about their thoughts relating to school, their self-perceived academic efficiency and their experiences related to English classes. The results show that the children $(N=17)$ generally have a positive attitude towards school work and English classes. In the English classes, ICT-supported learning (e.g. the use of tablets and smartboards) is present, which the students explicitly prefer compared to more traditional approaches. School attachment and attachment to the teacher in question also play an important role as the foundations of motivation in this work process.
\end{abstract}

\section{KEYWORDS}

focus group, learner attitudes, self-perceived academic efficiency, experiences related to English classes

\section{INTRODUCTION}

Following on from our previous research pertaining to the language learning process of disadvantaged children (which were conducted based on language teachers' experiences), this study aims to explore the attitudes of students. During the interviews conducted with disadvantaged children from fifth and sixth grade the focus was on what attitudes they have related to learning and schoolwork in general and, as part of this, on their attitudes toward the process of learning English. Bringing individual student opinions to light was also of utmost importance as

\footnotetext{
*Corresponding author. notin.agnes@gmail.com
} 
these can aid towards a more finely grained exploration of language learning attitudes and motivation within a heterogenous learner group.

This study took place as part of a series of digital learning material pilot studies developed by the MTA-DE Foreign Language Teaching Research Group (Fehér, Abari, Szökőcs, Tisza, \& Polonyi, 2018).

\section{THE BACKGROUND OF STUDENT SATISFACTION AND EFFICIENCY}

The attitudes of students toward school and learning are important markers of students' efficiency and the development of their personality. These attitudes also constitute one of the fundamental pillars of the quality of school work, which can be described as arising from a combination of multiple factors. One of these factors is student satisfaction, which develops from the learning process, performance and experiences outside of the classroom and contributes to school atmosphere. The role of efficiency as an essential element also comes into play as it shows how efficiently a system works when a given amount of effort is made. Good performance expected as a result of varied language teaching methods and its possible implications (e.g. a successful high school entrance exam or language exam) can serve as an example of the role of efficiency. A further factor is equity, especially in the case of disadvantaged students. In order to equalise students' chances, schools should, over time, diminish, compensate or improve the differences between students that stem from variation in both sociocultural background and inborn capabilities (Gyökös, 2015). The described processes jointly determine children's school experiences and expectations concerning their future.

Efficiency is mainly determined by the learning and achieving process in the classroom. Teachers, who are capable of working together with students in a differentiated manner towards the desired goal, play an exceptional role in this process. In this context, the meaning of differentiation is that while frontal methods work well with students of higher socioeconomic status, disadvantaged groups may achieve the best possible result with work in small groups and pair work (Sagi, 2017). The latter group also requires direct guidance and clearly defined rules to be able to overcome obstacles successfully. This phenomenon is best shown in terms of added value, i.e. the increase given by school in the development of children from various backgrounds and with different levels of knowledge. For this increase to appear, multiple factors need to be considered such as the prior performance of individual students, long-term opportunities for development of the target group, the multi-stage school system, factors aiding and inhibiting efficiency and indeed the definition of efficiency itself (Gyökös, 2015). Added value is especially important in the case of the student group studied here, as it is in the framework of added value that student satisfaction and expected performance can be interpreted.

A further factor making a large contribution to student efficiency is school attachment, i.e. the emotional ties connecting children to their school and the people in that school such as teachers or classmates. Alongside positive emotions, how students perceive, feel about and commit to institutional expectations and rules is also part of school attachment. It was found in a Hungarian study that the elements bearing the most influence on the strength of students' relationship with school were, in declining order, their attitudes towards school subjects, teacher-student relationships, how students relate to the school environment and students' peer relationships (Szabó, 2016; Szabó \& Virányi, 2011). Given stable attachment, students feel safe at school and are more motivated while learning. Naturally, students with different motives also have different attitudes towards school life and turn to school work with different expectations and conscientiousness. 
Another important element is responsibility taken for learning as a marker of conscious thought and decisions made by students about their own learning process, e.g. how much time is spent on learning, how thorough preparation for tests is and to what extent shortcomings and errors are considered (Szabó, Zsadányi, \& Szabó Hangyál, 2015). Therefore, it is of great importance that one bears in mind the following: student efficiency is influenced by the fact that school has considerable emotional significance for children in multiple ways with a further important role being played by children's targeted choices and commitment. It is especially important to investigate this in the case of disadvantaged children: the opportunity of attachment plays a determining role here as these children bring shortcomings with them that often inhibit them in experiencing efficiency.

Obviously, the situation is the same with language learning. It was found in a comprehensive study (Kuti, 2016) that the number of language lessons per week in a school setting was so important considering efficiency that it was even more important than the number of years previously spent learning the language. Thus, frequency and intensity are key in language acquisition; the students themselves considered a minimum of three lessons weekly to be ideal. Additionally, opportunities for language learning prior to the age of 10 were of exceptional importance: most participants felt it important that they had had the opportunity of starting to learn a foreign language early on. A further essential element of efficiency is the opportunity of practice in their free time. Having the chance of learning the language of their choice also contributes to student satisfaction.

The questionnaire used in the research mentioned in the previous paragraph also contains items pertaining to what role language teachers play in the learning process. Although the answers show that the presence of multiple language teachers can make the process more efficient, it is essentially an appropriate teacher-student relationship that provides the basis for and maintains students' motivation and efficiency. Based on students' opinions, the 'ideal language teacher' is consistent, supportive, open and cheerful, knows and loves the target language and is dedicated to their profession. Additionally, all these qualities contribute to the ideal language teacher' being able to create an inspiring atmosphere. Language learners also pose the following requirements: that their abilities and existing knowledge be taken into account, that the teacher's knowledge be up to date and that classes be centred around speech. In sum, students would like to playfully learn diverse and successfully learnable foreign language content in a positive atmosphere. (Kuti, 2016).

Therefore, it is the personal relationship between teacher and student, student effort and the professional competence of teachers that appear as central elements. It is based on these elements that our focus group interviews were constructed in order to study attitudes of children toward school and, within that, toward English language learning. In the case of these issues, it is especially important to look into individual differences as the word 'disadvantaged' can stand for a multitude of different life situations, personal experiences and ability structures.

\section{THE STUDY}

\section{Sample}

Participants of our research were two groups of students from two primary schools in Hajdú-Bihar county; the total number of participants was 17. In the education facilities in 
question, the ratio of disadvantaged students was approximately $40.3-50.55 \%$ in the $2016 / 17$ academic year (Buda, 2017). An important factor in the choice of the two schools for our research was that both schools had previously participated in a questionnaire survey carried out by the MTA-DE Foreign Language Teaching Research Group. Furthermore, all students participating in the questionnaire were later part of the experimental groups in testing the HANNA digital English teaching materials with tablets (Fehér, Abari, Szököcs, Tisza, \& Polonyi, 2018). The aim of the project is to enable disadvantaged upper primary school students to learn English in a classroom environment in a way that is playful and tailored to their individual abilities and interests.

The participants were Year 5 and Year 6 students; as for gender distribution, the groups were comprised of 9 girls and 8 boys. Students were selected for participation with the help of the schools' English language teachers in order that the groups be as heterogenous as possible. Accordingly, children showing weak, average and excellent performance based on their participation in English lessons and their grades were all part of the sample. Due to the school and settlement characteristics, the groups were mostly comprised of disadvantaged and multiply disadvantaged students. Special attention was paid to the heterogeneity of the groups considering both performance and ability levels. Having received some information from the language teachers, all children willingly took part in conversation during a class.

\section{Method}

We decided to use focus group interviews, which gave us the opportunity of obtaining a detailed picture of students' school experiences. Gaining extra information from interaction within the group is also an important advantage of this method. We compiled a semi-structured interview draft as is the norm when interviewing children (Vicsek, 2006); the importance of this will later be elaborated on.

The interviews took place in various classrooms within the schools taking part in the project, where we were able to talk to the children without interruptions. Each time there were 6-8 children in the group who came from two different classes in the same school. Prior to commencing the interview the English teachers introduced the interviewer to the children. Following this introduction, the children were left to talk to the interviewer in a calm atmosphere and with attention paid to preserving confidentiality. In the first few minutes the students received detailed information on the overall goal of the interview and were also able to state whether they consented to the interview being recorded on a dictaphone. Students agreed to being recorded in all cases and replied freely to questions posed to them. One of the important characteristics of such focus groups is that they aid the formation of spontaneous responses and another is that they also support the emergence of topics that may not have been included in the draft of questions but are important to the participants.

The draft was comprised of the following questions in the case of both groups:

1. What do they like about school?

2. What sort of student do they consider themselves to be?

3. What helps them learn well?

4. What is their attitude toward English lessons?

5. What would they change about school? 


\section{RESULTS}

The contents of the interview protocols were processed using the method of content analysis. Mutual or frequent responses recorded based on the answers provided by the children $(N=17)$ are presented for each question. In addition, individual answers that could contribute to a better understanding of the situation and thus aid the efficiency of the teaching-learning process in future will also be touched upon.

1. What do they like about school?

At the beginning of the interview our interest lay in students' general perception of their situation concerning school life and learning, i.e. what content comes to their minds in response to this question and how they themselves structure this content. Content types mentioned by the children are shown in the following in declining order of frequency:

- Learning (7)

The content mentioned most often was that school is an important place of gaining and expanding knowledge. Some emphasised that they were capable of learning new material quickly, which aids them in their current performance and their future efficiency. It was also mentioned by students that they liked the learning process provided that they received sufficient teacher explanations, opportunities for revision and a chance to gain more and more information over time.

"Well, that instead of learning the same material over and over again in every class even the teachers explain the material clearly and understandably."

"Well, that I can learn a lot of things here."

"I like learning because I know that it will help me achieve more."

- Subjects (5)

In addition to liking learning in general, various subjects and their related activities enjoyed or thought to be important by the students were also mentioned. Among the subjects spontaneously listed were English, Physical Education, Mathematics, Hungarian Literature and Science.

"Well, my favourite subjects are Hungarian Literature, P.E. and English."

"New knowledge in Mathematics. Especially Geometry."

"For me, it's Physical Education. Well, because I'm good at that. And it's easy."

- Social relationships (5)

The importance of friendships was emphasised by multiple students who said it was because of their friendships that they really enjoyed going to school. Teachers also play a significant role: the children expressed that they liked most of their teachers and that their teachers were kind and helpful during class.

"What's good about school for me is that all my friends are here, and the teachers are nice as well." 
"I made a lot of friends."

"Well, I like the teachers."

\section{- Extracurricular activities (4)}

This topic includes both clubs (e.g. English, robotics, football and art) and music lessons held in music schools such as piano lessons, recorder lessons or choir practice. One or two students also mentioned that performing in school ceremonies is especially important to them.

"There's the robotics club where we kind of play with Lego. That's my favourite. My second favourite is English club."

"For me it's that there is an art club."

"I went to recorder lessons last year. Played it for two years. And in Year 6 I went to graphics club."

The responses noted above were those more frequently mentioned during the focus group interviews. However, there were also a few unique answers to the question. One student said that school provides a way of structuring time in that 'time goes by quickly here.' Another student perceives school as 'a bit of relief from family' in the sense that they have less conflict at school than at home which is why school means a place of relief and safety to them in their everyday life.

\section{What sort of student do they consider themselves to be?}

The children were asked to judge their own school performance on a scale of 1-10. They were asked to do so in order to collect data about how they perceive themselves as students, independently of their grades. Five students rated themselves between six and seven, which were the lowest ratings given by the students. It thus shows that all interviewed students feel that they are students with an average or above average performance. Concerning the causes of changes in their ratings, these students mentioned how much energy they were currently able to spend on studying and how that invested energy paid off in their performance.

"I feel that I'm a six or seven out of ten. Depends on my diligence and my performance really."

"Well, when I feel like it. Sometimes I pay attention in class and that way I can learn."

There was one student who rated themselves with a stable seven points, followed by three students rating themselves with eight. Those who rated themselves between eight and nine emphasised the role of their mood causing them to put less or more effort into studying accordingly.

"Well it depends on how I feel."

Students giving nine points to themselves found studying easy and had a stable sense of efficiency. A further student gave themselves a rating between nine and ten. This student gave themselves this rating because they could not maintain their former excellent performance in this academic year as some of their grades had dropped.

"I would say nine and a half because I was an all fives ("straight-A") student for five years. . But I've received a lot of threes lately and that's why I would only give myself nine and a half....The subjects are a bit harder now, but I've corrected every grade and it's better now." 
Finally, two children gave themselves a ten. One gave no particular explanation as to why they gave themselves this rating and simply based it on their excellent performance. The other student was very modest and only uttered their rating when the others encouraged them. This student's uncertainty was caused by the fact that although they had a few fours in this academic year after having received an all fives report at the end of the previous academic year, they were still making considerable effort in order to perform well.

It can be said that this part of the interview was a good opportunity to explore the academic self-concept of the students. As can be seen from their answers, they try to focus on what they are capable of and what they can do to maintain the academic standards set by themselves based on their own previous work. As the expectations of adults did not appear directly in responses, it can be surmised that by the time children reach this stage of education (Years five and six), they have already interiorised the academic expectations of their parents and teachers. Another factor influencing responses could have been peer pressure, i.e. that the children wanted to show their peers that they do in fact have self-confidence and that they are generally satisfied with their own academic performance. Considering peers, answers could also have been influenced by a side of social comparison which has an effect on self-perception, even though this did not appear explicitly in the interview. Elements of this sort of social comparison are, for example, the academic performance of school-aged siblings, parents' level of education and direct or indirect feedback from teachers. A number of students mentioned that, due to the growth of learning material both in quantity and difficulty putting a strain on the learning process, concentrating their attention and maintaining interest will be more difficult as they step into adolescence and the upper primary level.

\section{What helps them learn well?}

In order to explore as many facets as possible of the above question, much attention was paid to detail concerning what sort of feedback lets the students know that they are doing well academically. It was also held to be important to investigate the locus of control and how students perceive their situation. Having analysed each student's response to the question individually, it can be said that in some cases academic success is perceived as a result of their own capabilities and efforts, while at other times their interpretation of the situation has more to do with external factors such as luck or chance.

- External reinforcement (5)

Multiple students emphasised that the way they perceive their academic success is mainly influenced by the grades received. Another type of reinforcement mentioned was the system of plus points where points can be collected to be later exchanged for a grade. Verbal praise from teachers also plays an important role concerning both participation in class and positive feedback after receiving a corrected test. Alternatively, it could simply be the case that the students perceive their finished work as well done due to external reinforcement having been given by the teacher. The students formulated their responses in the following ways:

"Well, if I get a good grade.... We get a five."

"Yes, and we also get plus points...If you have ten plus points you get a five." 
"When the teacher praises us. Like when she says well done or you've made good progress."

"Well I also feel it helps when the teacher praises me. And I also feel it if we write a test and it goes well."

- Learning strategies (3)

When answering the question, some of the children explicitly focused on the fact that for them, it was the process of task solving itself during studying and academic performance situations that gave them the feedback necessary to know they are performing at the required level. An example for such feedback is a student being able to precisely remember the English words they were currently learning at home. It was also mentioned that efficiency was also perceived by means of how quickly they were able to solve tasks, i.e. if they were able to recall learning material quickly and without much thought, it meant that the learning process must have been successful. This is exemplified by the following response:

"So far, I have fives (As) in every subject! For me being a good student means that when I read the material two or three times and recite it to myself, if there are five or six mistakes in my recital, I start again, read the material about five-six times and recite it to myself again. I do this until I can remember the material completely."

Both internal traits and characteristics perceived based on external factors were mentioned by six students. A few examples for the combination of these two views stand in the following:

"Well, I study a lot, and also based on my grades."

"Well, I have always been nervous whether I'll get a good grade or not, but at the moment I have a five in mathematics because I study mathematics a lot. And history, I'm doing pretty well in that too. And when we have tests, I feel I will do well on them."

Based on these responses, one can see that in a lot of cases, children are already capable of perceiving their expected performance in the learning process and that the grades and feedback they receive for their performance further strengthen their expectations. Of course, the children's recognition of the connection between these factors has a solid foundation in prior school experiences, since they know what outcome a given amount of effort and perseverance will have based on their own capabilities and their teachers' expectations.

\section{What is their attitude toward English lessons?}

Students were asked what their attitude was towards English lessons and the activities done regularly in these classes. A number of students emphasised that they liked English, felt that they were capable of mastering the current learning material and that English classes were held in an especially fluid and playful way. It is worth mentioning that the children spoke about all facets of English classes (apart from a few pieces of grammar perceived to be particularly difficult) with much optimism and enthusiasm. The elements mentioned most often by the children are presented in the following. 


\section{a. Equipment}

The most prominent piece of equipment of all was the tablet. As the children can use a tablet quickly and with ease, they engage willingly in tasks and feel efficient during solving those tasks. A few students mentioned that they prefer tablet supported tasks to tasks to be solved in speech or writing, so much so that they could even picture themselves working with tablets only in English classes, mentioning tablet-supported vocabulary learning as an example. Laptop and interactive whiteboard use in class were also mentioned; the students were able to successfully follow and solve the tasks designated by the teacher with the help of these instruments. The following sentences cited from the students themselves support these observations:

"When we use the tablets. Or when we're not using the tablets, but we're always connecting the projector and the laptop and then the teacher shows what needs to be done."

"I think that because this technology exists you don't need to learn it quite like you used to, so it was harder. Instead, let's see, you connect the earphones to a tablet or phone, listen to it like that and then you understand a bit later."

"I like playful learning, like we use tablets in English class."

"We don't write so much, our fingers don't get tired. And that we don't have to recite the material orally, instead, the machine speaks and then we learn from it. We don't need to talk."

"It's easier to study with it. And, well, you learn more English words."

"And the way we do it is we project it from the laptop and turn the page. And then we always have a look and see that there's always a short video or part of one related to the topic."

"And there was also this time when we needed to find an object on the smartboard and then it was written on the board what that object was. You needed to pair them up."

Apart from widely used basic equipment such as textbooks, workbooks and vocabulary books, one of the groups also mentioned word cards, balls, toy bombs, blackboards and CD players as equipment bearing multiple functions in language classes.

"Sometimes we pick a card and we have to say what's on the card. Well, 'trolley', 'taxi', 'plane', "hotel'."

"A small bomb, about this big. Well, the thing is it ticks, and you need to say the word or sentence before it goes off. We need to say as many words that we have learnt as we can before it goes off. And the ball."

"We need to throw the ball to each other and ask a question for the other person to answer."

"We also play a game where the teacher puts circles on the board, and she writes words in them..."

"The teacher sometimes brings a CD player in, puts a CD in it and plays it. Then afterwards we have to write down what we've just heard. ... we repeat it, then the teacher stops the CD. . She asks what the new word was in it that we haven't learnt yet."

Based on the accounts of the children, all these pieces of equipment are frequently used during the activities they like doing. The use of this equipment helps language teachers to aid interactive pair and group work, give more emphasis to teacher's explanation and 
support both learning of new material and activating previously learnt knowledge. Using these aids also provides the possibility of conveying information to the students on multiple modalities, thus helping students to be more successful in learning English.

b. Task types

Of the students who mentioned what sort of tasks they preferred in English classes, most mentioned speaking activities, listing class dialogue and the recital of rote-learnt tests as their favourite activities. Tasks including video or other visual material, such as pairing up pictures with words or describing a pictured object in English (this is part of a Hungarian game known as Activity), were also popular.

"And when we recite the texts that we were given to learn.... It's good that it doesn't need to be written down and we don't need to remember how to write it down."

"Speech itself, that the teacher is talking to us in English in class; understanding what the teacher says is a challenge."

"We talk to each other as well in another language."

"The best for me are videos because I can learn more from those."

"I like Activity and also hangman."

"I like tasks like when there's a text on a piece of paper in English and then it needs to be translated into Hungarian."

"Sometimes we get a text and questions about it in English. There was $a, b$, and c and some animals and people were written there, or I don't know. And then in the text... you needed to find them. Yes. And then we needed to interpret the text."

"I like crosswords."

c. Topics

The most popular topics were those concerning traditions, festivities and everyday activities. Among the topics listed were Christmas, birthdays and free time. Nature, animals, countries, transport and verb tenses were mentioned on one occasion each.

"Everything's good. The past, present and future tenses. . the words 'holiday' and 'celebrate'."

"Well, I like to learn about animals and nature."

During the interview, the subject of what the students do not like was also brought up. It was mentioned by some of them that they found certain past tense forms, spelling and telling the time especially difficult, so much so that they could not feel they could confidently recall and use the mentioned language elements even after repeated practice.

"The grammar...because there's 'was' and 'were'...And 'did', that's hard!"

"Well, it's difficult for me to write down. . The spelling."

"I don't understand the clock very well. I don't understand the bit about 'half past' and why we learn it this way." 
While students were asked about their attitudes towards English classes, a number of the children concentrated their answers on why English language competence will be useful to them in future instead. In most cases we could detect instrumental motivation (Nikolov, 2003), i.e. that English is seen as a tool for success in certain areas in future. For example, it can be useful for living abroad, for success at work and for leisure trips. The following sentences exemplify the previous observations:

"What I like in English is that they speak it everywhere in the world. Here, we're always developing our vocabulary. And when we go abroad, it will be much easier for us to fit in."

"I like it because I'd like to be a tour guide and English will help me when I start working."

"I like it because when we go abroad it's easier to talk to people this way."

\section{What would they change about school?}

At the end of the focus group interviews, students were asked to elaborate on what they would change about school work if it were up to them. This was done in order to allow for the articulation of possibly covert needs and ideas, thus laying the foundations for a higher degree of efficiency in future interventions concerning the children. Students were happy to answer these questions and gave, apart from a few unrealistic ideas, practical and constructive recommendations for change, which can be sorted into the following categories:

- Time schedule

The most frequently mentioned item in the responses was school time, with special attention to daily starting and finishing times. According to the students, starting at 9 instead of 8 a.m. would be better as this would help them start the day well rested and more awake. For this to be possible, they would even willingly stay at school until 5 or 6 p.m. to finish all classes and extracurricular activities. A few, however, would prefer a smaller amount of lessons, which could be longer than the current standard of 45 minutes. In most cases, responses were influenced by personal wants and attitudes in connection with changes taking place in adolescence (for example more time for sleep and organising tasks based on personal interest).

"To be able to get up later. . at least an hour later. . to come in for 9."

"I'd change it so we'd come to school at 10 and go home at 6 because then we could sleep a lot."

"I would have liked to say that it would be better to have 5 lessons a day instead of 6-7. And then those lessons could be 50 minutes long instead of 45 to make up lost ground."

- Learning process and workload

In some responses, wishes were expressed to take certain subjects such as History or Hungarian Grammar off the curriculum. Alternatively, other responses contained the idea of substituting subjects with other subjects such as Independent Study. The idea of taking subjects off the curriculum had its roots in lack of student motivation, a negative attitude toward the teacher of the subject in question or difficulty in performing well in the subject. There was also a response containing the idea of starting to learn certain subjects at an earlier stage in school. 
"I'd remove Maths, Nature Studies and History."

"Oh, and I'd bring a few subjects forward. Geography, for example. I'd bring Geography forward."

Another main line of thought in this category was that there should be more emphasis on the use of digital equipment in the classroom, i.e. that all students should have a laptop or tablet with them, and the teacher should use the interactive whiteboard throughout the whole lesson. Accordingly, printed textbooks would gradually disappear from classroom work. This would in turn reduce the amount of materials needed in the classroom and physical strain, as it would be easier to carry a single tablet than all the different textbooks and exercise books. Additionally, it would help strengthen the previously mentioned practice of using vocabulary cards and games, i.e. 'playful learning,' which is strongly preferred by the students.

"In that we wouldn't need to bring books, only tablets. And books could be downloaded onto tablets."

"Our schoolbags wouldn't be so heavy so they wouldn't make our spines curved."

\section{TEACHER AND STUDENT EXPERIENCES: THE TWO SIDES OF THE COIN}

Interviews conducted with teachers in May 2017 can partially be coupled with the results of the current focus groups as we worked with the children who were taught by the teachers interviewed previously. It can be said that the interviewed students like English lessons and strive to meet expectations. The English teachers themselves play an important role in the language learning process, providing varied language input such as listening activities and pair work both in class and in English club in the afternoon. Thanks to frequent revision and knowledge testing, the children can partially recall which part of language material was learnt with what classroom activities. These activities are well-prepared tasks in line with the capabilities and knowledge of the students.

Task types and equipment mentioned by the teachers, such as Activity and vocabulary cards, were also included in the responses given by children to the questions asked in the interview. Teacher and student opinions were also the same in that the students like visual and auditive task types and are capable of solving these tasks at the level the teacher expects. Tablets introduced at the beginning of the school year and trialled throughout the year received an important role concerning this question. The children elaborated on the tablet-related tasks and their first experiences in detail and also made recommendations concerning future developments. Students making good progress obviously see themselves as successful, can recall their experiences related to English classes with great precision, decidedly like English classes and even consider knowledge of this language useful at a comparatively young age.

Student satisfaction and students' attitudes towards the English language are largely dependant on previously established teacher-student relationships, i.e. on affective motivation mentioned in classic theories (Kozéki, 1985). Any mention of their teachers bore evidence of a warm, attentive and encouraging teacher attitude. Well varied tasks, constant preparation, fair evaluation and verbal praise were all important for the children, contributing to maintaining their motivation related to language learning. All this reflects years of work which is, in addition to methodological and subject knowledge, largely dependant on the nature of personal 
connection, taking children's personalities into account and the incorporation and acceptance of any shortcomings. A positive teacher attitude plays a determinative role in the learning process despite noticeable language inadequacies, motivational problems and changes related to adolescence. Additionally, the presence of performance criteria and rules pertaining to classroom behaviour helps the students make progress in their English studies and feel that they are able to meet expectations on at least an adequate level.

\section{CONCLUSION}

For the primary school children participating in our research $(N=17)$, school is not only a place where one must study but also a space in which they have the opportunity of optimal academic progress despite their possible shortcomings. Accordingly, they also receive opportunities which can aid them in their further studies and getting into higher education. Foreign language lessons, which constitute the focus of this study, are such an opportunity. Having the chance of revising and catching up when necessary is important to these children. Some subjects, such as English, Hungarian Literature and Physical Education are preferred due to the nature of covered material, teaching methods and the personality of the teacher in question. The students strive to learn diligently and attentively within their own capabilities, provided that the received task is perceived as solvable at their level. Naturally, extracurricular activities such as English club, robotics club or football practice also bear great importance to them as these provide opportunities for building relationships with peers and showing knowledge and capabilities not closely related to any particular subject.

The children interviewed see themselves as capable of performing at an average or good level at school as none mentioned a lower level than average in front of the others in order to maintain a positive self-image and their role within the group. Some students perceive themselves as excellent based on their almost straight-A school reports. How the children evaluate themselves is strongly dependent on their grades, plus points and teacher feedback. Thus, by the time they start upper primary school, students are capable of realistically judging how successful they are based on their experiences with learning and performance. It was mentioned by multiple students that it becomes obvious to them that they have successfully learnt the given learning material if they revise enough when studying at home or if they can write tests quickly and without much further thought.

When asked about their experiences with English, the students elaborated on equipment, tasks and topics in their English lessons over the past years with ease. In addition to traditional equipment, digital devices such as interactive whiteboards and tablets have also been added to the repertoire in school work. It became clear in the focus group interviews that the students welcomed this change, as with the help of these devices they reported that they are able to learn current material easily, quickly and in multiple modalities at the same time. In their opinion, it is in this digital equipment that the future lies: printed textbooks and handouts could be eliminated, they would need to carry less in their schoolbags, and they could continue practicing at home. In addition, students remember tablet-related classroom tasks well and would continue practicing the English tasks designed for tablets with pleasure at any time.

As can be seen from our analysis, the students involved in these interviews are motivated concerning school work despite the fact that there are a few elements (e.g. their time schedule 
and certain parts of the learning process) that they would like to change. For these students, it can be said that learning is the key to development. This study is non-representative as it was centred around students from two schools in Hajdú-Bihar county. The students involved go to schools in disadvantaged regions and most of the children in these schools are multiply disadvantaged and require special treatment. In such a situation, the role of teachers becomes even more important since it is their supportive academic and personal work that lays the foundations for their students' confidence in their own future and thus for the necessity of maintaining efforts and perseverance.

Ethics: This study was approved by the Institutional Review Board of the Institute of Educational Studies and Cultural Management (University of Debrecen).

Funding sources: This study was supported by the Hungarian Academy of Sciences in order to provide innovative digital supplementary course materials in English for pupils coming from low SES environments.

Authors' contribution: All authors had full access to both the design and concept of the study and the interpretation of data.

Conflict of interest: The authors declare that they have no conflict of interest.

\section{ACKNOWLEDGEMENT}

The authors do not wish to make any additional acknowledgements.

\section{ABOUT THE AUTHORS}

Ágnes Nótin is a psychologist who received her MA in Psychology with a specialisation in counselling and school psychology in 2011 at the Psychology Institute of the University of Debrecen. Her main research area lies in the occurrence of school anxiety among high school students. Since 2017 she has been a member and research organisational colleague of the Foreign Language Teaching Research Group which is a joint research group of the Institute of Psychology at the University of Debrecen and the Hungarian Academy of Sciences.

Anna Ware is a student who is majoring in English and German in the teacher training programme at the University of Debrecen and has an interest in educational studies.

\section{REFERENCES}

Buda, M. (2017). Helyzetfelmérés hátrányos helyzetü iskolákban. Manuscript. Debrecen: MTA-DE Idegen Nyelvi Oktatás Kutatócsoport. 
Fehér, J., Abari, K., Szökőcs, B., Tisza, K. A., \& Polonyi, T. (2018). HANNA - Angol digitális nyelvoktató tananyag. In T. Polonyi, \& K. Abari (szerk.), Pszichológia - Pedagógia - technológia (pp. 119-142). Budapest: Oriold és Társai Kiadó.

Gyökös, E. (2015). Az iskolák teljesítményének nyomában - Az eredményességtől a hozzáadott értékig. In M. Szemerszki (szerk.), Eredményesség az oktatásban - Dimenziók és megközelitések. Budapest: Oktatáskutató és Fejlesztő Intézet.

Kozéki, B. (1985). Motiválás és motiváció. Budapest: A pedagógiai időszerükérdései hazánkban. Tankönyvkiadó.

Kuti, Z. (2016). „Te mit gondolsz a nyelvoktatásról?” Összefoglaló a Nyelvtudásért Egyesület nyelvtanulók és nyelvtanárok körében végzett felmérésének eredményeiről. In Z. Kuti, \& Ö. Enikő (szerk.), Mi a baj az iskolai nyelvoktatással? Conference summary. Budapest: Nyelvtudásért Egyesület.

Nikolov, M. (2003). Angolul és németül tanuló diákok nyelvtanulási attitüdje és motivációja. Iskolakultúra, $8,61-73$.

Sági, M. (2017). Different students, different impacts? Effect of school characteristics on disadvantages and advantages students' learning outcome. Hungarian Educational Research Journal, 7(4), 117-120.

Szabó, F. (2016). The motivational force of employing literature in a foreign language classroom. Hungarian Educational Research Journal, 6(1), 61-70. https://doi.org/10.14413/HERJ.2016.04.05.

Szabó, É., \& Virányi, B. (2011). Az iskolai kötődés jelentősége és vizsgálata. Magyar Pedagógia, 111(2), 111125.

Szabó, É., Zsadányi, Z., \& Szabó Hangyál, L. (2015). Ki szeret iskolába járni? Az iskolai kötődés, a motiváció, az énhatékonyság és a tanulmányifelelősség-vállalás vizsgálata. Iskolakultúra, 10, 5-20.

Vicsek, L. (2006). Fókuszcsoport. Budapest: Osiris Kiadó.

Open Access statement. This is an open-access article distributed under the terms of the Creative Commons Attribution 4.0 International License (https://creativecommons.org/licenses/by/4.0/), which permits unrestricted use, distribution, and reproduction in any medium, provided the original author and source are credited, a link to the CC License is provided, and changes - if any - are indicated. (SID_1) 